\title{
Applying Value Stream Mapping to reduce food losses and wastes in supply chains: a systematic review
}

\author{
Hans De Steur ${ }^{a}$, Joshua Wesana ${ }^{a, b, *}$, Manoj K Dorac, Darian Pearce ${ }^{\mathrm{a}}$ and Xavier Gellynck ${ }^{\mathrm{a}}$ \\ ${ }^{a}$ Department of Agricultural Economics, Faculty of Biosciences Engineering, Ghent University, Ghent, Belgium. \\ ${ }^{\mathrm{b}}$ School of Agricultural and Environmental Sciences, Mountains of the Moon University, Fort Portal, Uganda. \\ ${ }^{c}$ College of Business, Arts \& Social Sciences, Brunel Business School, Brunel University, London, United Kingdom.
}

* Corresponding author: Department of Agricultural Economics, Ghent University, Coupure Links 653, 9000 Ghent, Belgium.

T: +32 926459 45, F: +32 926462 46. Email: Joshua.Wesana@UGent.be, wesanaj@yahoo.com.

HDS and JW contributed equally to this work and shall be considered as co-first authors 


\begin{abstract}
:
The interest to reduce food losses and wastes has grown considerably in order to guarantee adequate food for the fast growing population. A systematic review was used to show the potential of Value Stream Mapping (VSM) not only to identify and reduce food losses and wastes, but also as a way to establish links with nutrient retention in supply chains. The review compiled literature from 24 studies that applied VSM in the agri-food industry. Primary production, processing, storage, food service and/or consumption were identified as susceptible hotspots for losses and wastes. Results further revealed discarding and nutrient loss, most especially at the processing level, as the main forms of loss/waste in food, which were adapted to four out of seven lean manufacturing wastes (i.e. defect, unnecessary inventory, overproduction and inappropriate processing). This paper presents the state of the art of applying lean manufacturing practices in the agri-food industry by identifying lead time as the most applicable performance indicator. VSM was also found to be compatible with other lean tools such as Just-In-Time and 5S which are continuous improvement strategies, as well as simulation modelling that enhances adoption. In order to ensure successful application of lean practices aimed at minimizing food or nutrient losses and wastes, multistakeholder collaboration along the entire food supply chain is indispensable.
\end{abstract}

Key words: food supply chain; food loss; food waste; lean manufacturing; nutrient loss; Value Stream Mapping 


\section{Introduction}

The year 2016 represents the start of the global challenge for reaching the UN Sustainable Development Goals (SDGs) (Kumar et al., 2016; Sachs, 2012). While there is no doubt that the Millennium Development Goals (MDGs) accelerated progress in fighting hunger and malnutrition between 2000 and 2015, the major threat to food security in the SDG-era is expected to be reinforced by population growth and adverse climatic changes (Hanjra et al., 2013; Wheeler and von Braun, 2013). And although increasing food production as such is often considered as a key solution, it comes at a high cost i.e. utilizing the already scarce resources such as clean water, land, protected areas and forests, that are necessary for a healthy environment and biodiversity (Godfray et al., 2010; Phalan et al., 2011). Since onethird of food produced is lost or wasted along the supply chain (Gustavsson et al., 2011), dedicated efforts ought to be directed toward the implementation of innovative measures from farm to fork, thereby not only ensuring the delivery of significant quantities of food, but also retaining the level of nutrients in those foods (Ruel et al., 2013). In this context, literature distinguishes "food losses", a decrease in edible food mass occurring during production, postharvest and processing from "food wastes", any raw or cooked food mass that is discarded at retail and consumption (Gustavsson et al., 2011; Kummu et al., 2012; Miller and Welch, 2013; Parfitt et al., 2010). Together, they are defined as "food supply chain losses”, referring to each stage along the chain where a given proportion of food that is initially meant for consumption does not reach the intended consumer (Richter and Bokelmann, 2016; Willersinn et al., 2015).

From an economic point of view, initiatives that tackle food losses and wastes (FLW) are not only beneficial to those food producers aiming to sell more, but also to consumers who could 
save money as the available food becomes more affordable (Rutten, 2013), and enhance their energy and nutrient intake, when also quality losses in food would be addressed (Almdal et al., 2003; Barton et al., 2000; Edwards and Nash, 1999). A study by Rutten (2013) shows that reduction of FLW has potential to lower food prices particularly in favour of net food consumers but not net food producers. Similarly, FLW reduction efforts in developed countries might lower food prices in developing countries (Rutten et al., 2015), save resources that can be used to feed a hungry population and boost efficiency along their supply chains (Buzby and Hyman, 2012). Although such changes are said to potentially improve accessibility to nutritious foods among vulnerable households (Brinkman et al., 2010; Gustavsson et al., 2011), there is need to better address food and nutrient losses or wastes simultaneously in order to reach some of the SDGs. First of all, perishable products that are highly nutritious such as vegetables, fruits, dairy, meat and fish, are often more prone to loss and wastage along the supply chain than staple foods, like cereals (Yu and Nagurney, 2013). Post-harvest losses in such foods are singled out as a factor that affects availability and accessibility to poor individuals (Murthy et al., 2009). Second, through reducing weight or size of edible parts of plants or animals, an estimated $25 \%$ loss of available calories eventually are not consumed (Searchinger et al., 2013). When half of such FLW along the supply chain would be reduced, the nutritional requirements of about 63 million undernourished people from developing regions would be met (Munesue et al., 2015). In addition, food processing activities such as inappropriate peeling and cutting are known to not only lead to quantitative FLW, but also compromise the micronutrient quality (Artés et al., 2007; Francis et al., 2012). Vitamin C and A, for example, are easily lost in fresh cut fruits as compared to whole fruits due to the processing operations (Barrett et al., 2010; Gil et al., 2006). This approach of tackling both food and nutrient losses, can reinforce agriculturenutrition linkages and ultimately contribute to food and nutrition security (Pangaribowo et al., 2013). 
Lean manufacturing, a quality management approach initially developed to eliminate waste in the automobile sector, is defined as "a system that utilizes fewer inputs and creates the same outputs while contributing more value to customers" (Womack et al., 1990). It is viewed as a philosophy rather than just a collection of tools (Hines et al., 2004), and can be considered as a gateway to a systems thinking that requires collaboration of all value chain actors with a collective goal to boost customer satisfaction (Halloran et al., 2014). Identification and elimination of wastes (non-value adding activities) is key to the concept of lean manufacturing, and its application is currently not only limited to the automobile sector, but also has increasingly been applied in other sectors particularly the agri-food industry (Dora et al., 2014; Zokaei and Simons, 2006a). Nevertheless, its penetration into the agricultural sector has been slow and this is attributed to the perishability of a wide range of food products, complexity of the agri-food supply chain and dynamic consumer preferences (Dora et al., 2016). Regardless of the fact that not all lean tools can easily be adapted to a new processing industry, Value Stream Mapping (VSM), defined as “a tool that helps you to see and understand the flow of materials and information of a product as it makes its way through the value stream” (Rother and Shook, 1998), has found its way into the agri-food industry (Panwar et al., 2015). It involves identifying seven lean wastes (i.e. defects, overproduction, inappropriate processing, unnecessary inventory, unnecessary motion, transport \& waiting (Hines and Rich (1997)) through the development of a current and, through the application of other lean tools, a future state value stream map (Dal Forno et al., 2014; Womack, 2006). Its success has for example been shown in its ability to improve the effectiveness of value chain analysis by enhancing consumer value at each stage (Zokaei and Simons, 2006b), boost food production and service (Ahmed et al., 2015), minimize wastes in convenience food manufacture (Darlington and Rahimifard, 2006) and improve efficiency of a food contract manufacturer (Lehtinen and Torkko, 2005). Although previous studies justify its use in 
various industries as a tool to curb waste, none to the best of our knowledge has explicitly explored its adaptability to FLW with a specific link to nutrient retention; yet the potential exists.

Based on a systematic review approach, this study is considered the first to aggregate and examine evidence on the application of VSM in the agri-food industry. Thereby, specific attention was devoted to the potential of VSM to be combined with other methods targeting the elimination of FLW, as well as its adaptability for identification and measuring nutrient losses. The next section of this article outlines the procedure that was used to search and select studies, from which relevant data was obtained. The third section gives an overview of studies characteristics, application of lean manufacturing mainly focusing on VSM and identification of losses and wastes. The fourth section is devoted to a discussion of important findings which is followed by a conclusion.

\section{Methods}

The structure of this systematic review followed applicable guidelines set in the Preferred Reporting Items for Systematic Reviews and Meta-Analyses (PRISMA) Statement. In addition, the search for data, synthesis and conceptualization of data from relevant studies was based on Petticrew and Roberts (2008), complemented with qualitative content analysis process suggested by Hsieh and Shannon (2005).

\subsection{Search strategy}

Studies were identified by searching ISI Web of Science, Scopus, AgEcon and google scholar databases from 1990 to 2015. This time period was selected in order to cover a timeframe from when lean manufacturing started to be documented in literature to date (Womack et al., 1990). 
The search targeted articles written in English and was not only limited to studies published in indexed Journals. Exclusion of articles from non-indexed journals has previously been discouraged in order to ensure that important literature is not missed (Frewer et al., 2013). Manuals, editorials and commentaries were disregarded. The search syntax used included the following search terms referring to lean and VSM (value stream mapping, lean manufacturing, lean management, lean philosophy, lean thinking, lean principles, lean practices and lean tools), combined with food related terms (food, food supply chain, agrifood chain, food industry, food sector and agriculture). For confirmatory purposes and to identify additional studies, a reference list of a recent review on adoption of lean principles (Panwar et al., 2015) was also utilized. The search for articles was done in October 2015 by two researchers, cross-checking each other at every search step as a control.

\subsection{Study selection}

The inclusion criteria used for selection of relevant studies, after removal of doubles, was initially based on title and abstract screening to ascertain the existence of both lean and food related key words (Figure 1). A full paper review was performed where a more stringent inclusion criteria was applied. Studies that utilized VSM as (one of) the lean tool(s) were retained to constitute the systematic review. Further a study had to focus on at least one supply chain actor i.e. primary producers, processors, distributors, food service and/or consumers. There was no restriction applied on whether a study aimed at the identification and elimination of losses and wastes. Studies that did not explicitly examine this were included, as they still applied VSM with elements that can be related to loss and waste identification and elimination.

[Insert Figure 1 here]

2.3 Data extraction and quality assessment 
A data extraction sheet was designed based on reviewed studies, specifically for lean manufacturing and agri-food data. In addition to study characteristics normally reported in systematic reviews and after performing a pilot test extraction, the sheet was used to systematically record and code necessary data from the studies. We extracted information related to; level of analysis, targeted supply chain actor, type of food product, country, year of publication, study design, method of data collection, application of VSM (state maps, other lean tools, lean metrics and use of simulation), type of- and reason for- waste. With regards to lean metrics (e.g. lead time, takt time, cycle time and number of operators), performance improvement was calculated based on the difference between the current and future state, and expressed in terms of a percentage reduction in a given metric (Dora et al., 2016). These elements facilitated the formulation of a comprehensive narrative with an overview of selected studies with respect to their characteristics, application of VSM and the reported food or nutrient losses and wastes. Quality appraisal of included studies was performed by adapting a validated methodological scoring system developed for assessment of qualitative, quantitative and mixed methods studies (Pace et al., 2012; Pluye et al., 2009; Souto et al., 2015). The assessment used five parameters, that were considered relevant to the current study, as defined by the scoring system (Table 1). Studies included scored relatively well on quality i.e. the average quality score from all studies was 4 of a maximum score of 5 . No study was excluded based a quality score, rather inadequacies with application of VSM methodology were discussed in our findings.

[Insert Table 1 here]

\section{Results}

\subsection{Study characteristics}

As the flow chart (Figure 1) illustrates, the search initially identified 2218 studies that were of potential relevance. However after removing doubles, title, abstract and full article screening, 
a total of 24 studies were selected, classified based on the number of supply chain actors (Table 2). All studies were published from 2003 onwards, using a case-study approach to collect data from interviews, focus groups, observations and records or a combination of these. Among High Income countries, most studies (10/15) were conducted in the United Kingdom. This is largely attributed to the development of a Food Value Chain Analysis methodology (FVCA) based on lean philosophy, which was commissioned by the government and implemented in various agri-food sectors from 2002 (Taylor, 2006a). Among Low Income countries, India had three studies more than any Asian country, and while two studies originated from South America, one was an African study from Zimbabwe. Of the twenty four studies, nineteen applied VSM in a single agri-food plant setting, of which fifteen focused on a food processing company, producing; bread (Goriwondo et al., 2011; Sathiyabama and Dasan, 2013), ready to eat foods (Darlington and Rahimifard, 2006; Kennedy et al., 2013), peaches (Folinas et al., 2015), wine (Jiménez et al., 2012), mango juice (Hossain and Uddin, 2015), ketchup (Lehtinen and Torkko, 2005), yogurt (Melvin and Baglee, 2008), biscuit (Noorwali, 2013; Shobha and Subramanya, 2012), coffee (Parthanadee and Buddhakulsomsiri, 2014), snacks (Sa’udah et al., 2015), nougat (Tanco et al., 2013) or tea (Vlachos, 2015). Furthermore, studies on single chain members targeted the food service sector, i.e. two hospital kitchens delivering a variety of foods such as bread, soups and processed vegetables (Ahmed et al., 2015; Engelund et al., 2009) versus fast food restaurants (Rahimnia et al., 2009), or a food warehouse (Glover et al., 2014). Five studies have analysed more than one actor along the food chain. While the study by Francis et al. (2008) examined a beef producing farm and processing factory, four other studies also included a retailer, e.g. in a chain producing lamb (Simons et al., 2003) and pork (Taylor, 2005, 2006b), or both wholesaler and retailer, i.e. in an edible oil supply chain (Seth et al., 2008).

\subsection{Application of VSM, additional lean tools and performance indicators}


With regard to application of VSM in a given agri-food context (Table 2), majority of studies used a mapping technique and developed both current and future state maps i.e. ten studies at the single plant level (Folinas et al., 2015; Glover et al., 2014; Goriwondo et al., 2011; Hossain and Uddin, 2015; Jiménez et al., 2012; Parthanadee and Buddhakulsomsiri, 2014; Rahimnia et al., 2009; Sa’udah et al., 2015; Shobha and Subramanya, 2012; Tanco et al., 2013) and two studies at the supply chain level (Seth et al., 2008; Taylor, 2005). Although state maps were in general graphically illustrated, two additional studies (Engelund et al., 2009; Sathiyabama and Dasan, 2013) only described the current and future states. There were six studies (Ahmed et al., 2015; Darlington and Rahimifard, 2006; Kennedy et al., 2013; Lehtinen and Torkko, 2005; Melvin and Baglee, 2008; Vlachos, 2015) that only used the current state map and one study (Noorwali, 2013) that gave a description of the current situation at a single plant level, against three studies (Francis et al., 2008; Simons et al., 2003; Taylor, 2006b) at a supply chain level.

Except for three studies (Folinas et al., 2015; Seth et al., 2008; Taylor, 2005), all case-studies with both maps used lead time, takt time and/or number of operators as lean manufacturing metrics to calculate performance improvements in food production processes. At a single plant level, comparison between current and future situations resulted in a reduction of 3-83\% (lead time), 2\% (takt time) and 7-40\% (number of operators) among processors. A reduction of $83 \%$ and $75 \%$ in lead time at storage and consumption, respectively, was also observed. One study conducted at a supply chain level illustrated a reduction of $93 \%$ in lead time (Seth et al., 2008). Among those studies that included only current state mapping, four reported an associated lead time (Darlington and Rahimifard, 2006; Lehtinen and Torkko, 2005; Taylor, 2006b; Vlachos, 2015), one cycle time (Simons et al., 2003) while four studies reported none (Ahmed et al., 2015; Francis et al., 2008; Kennedy et al., 2013; Melvin and Baglee, 2008). Finally, only one study (Noorwali, 2013) did not report any lean metric. 
For continuous improvement (i.e. Kaizen), a requirement for achieving objectives in lean manufacturing, a number of additional tools were utilized either alone or in combination in various agri-food entities. Just-In-Time (JIT) or pull strategy was the most applied alongside VSM in nine studies (Darlington and Rahimifard, 2006; Folinas et al., 2015; Hossain and Uddin, 2015; Jiménez et al., 2012; Shobha and Subramanya, 2012; Tanco et al., 2013; Taylor, 2005, 2006b; Vlachos, 2015) at both levels of analysis. 5S (sort, set in order, shine, standardize and sustain) methodology was mainly used in six studies (Engelund et al., 2009; Glover et al., 2014; Hossain and Uddin, 2015; Jiménez et al., 2012; Kennedy et al., 2013; Sathiyabama and Dasan, 2013) at a single plant level only. Other lean tools used included Kanban (Jiménez et al., 2012; Shobha and Subramanya, 2012), visual aids (Francis et al., 2008; Lehtinen and Torkko, 2005) and cellular manufacturing involving a reorganisation of fast food restaurants based on two distinct customer needs (Rahimnia et al., 2009). While all studies adopted the VSM approach and associated tools to some extent, five studies also integrated a simulation modelling technique in their analyses (Darlington and Rahimifard, 2006; Noorwali, 2013; Parthanadee and Buddhakulsomsiri, 2014; Sa’udah et al., 2015; Tanco et al., 2013).

\section{[Insert Table 2 here]}

\subsection{Identification of loss and waste}

Out of the twenty four studies reviewed, twenty referred to waste identification and/or elimination, e.g. susceptible supply chain hotspots, type of loss/waste (including a categorization based on the seven lean wastes) and the specific reason(s) behind the identified losses/wastes (Table 3). Two types of losses/wastes became evident i.e. discard waste in all studies while nutrient losses potentially occurred in two studies. As such both could be attributed to comparatively similar lean wastes at a particular supply chain hotspot i.e. primary production, processing, storage and food service/consumption. 


\subsubsection{Defects in product}

This lean waste was present at all four supply chain hotspots and was associated with discarded food. In a study analysing a pork chain, incorrect weight and fat levels at primary production were considered as product defects (Taylor, 2005).

Similarly, defects in food processing companies arose from poor/overtopping, over baking, variation in size and shape (Sathiyabama and Dasan, 2013), breakages (Goriwondo et al., 2011) in the production of bread, scrap or poor quality in peach (Folinas et al., 2015), biscuit (Noorwali, 2013; Shobha and Subramanya, 2012), pork (Taylor, 2005, 2006b) wine (Jiménez et al., 2012), tea (Vlachos, 2015) and edible oil (Seth et al., 2008) production. Further, microbial spoilage associated with short shelf life as a defect at processing resulted from repetitive handling by operators (Darlington and Rahimifard, 2006; Francis et al., 2008; Melvin and Baglee, 2008), contact with contaminated surfaces (Francis et al., 2008) and cooling at a slow rate (Melvin and Baglee, 2008).

Defects also occurred during storage in a study where food was exposed to ambient temperature for prolonged periods (Glover et al., 2014). With regards to food service, wrong meal service in hospital kitchens (Ahmed et al., 2015) and mismatching of customized needs for consumers at fast food restaurants constitute defects (Rahimnia et al., 2009). In the case where overbaked products were discarded in a study involving bread manufacture (Sathiyabama and Dasan, 2013), it is more likely that heat labile micronutrients were also lost.

\subsubsection{Unnecessary inventory}

At the farm level, unused inventory could be disposed of as waste culminating from an uncertain supply of raw materials used to produce edible oil (Seth et al., 2008) and the use of a push system in production of pork (Taylor, 2005, 2006b). This was more or less similar in food processing companies in situations where there was an accumulation of either raw materials or finished products more than required (Lehtinen and Torkko, 2005; Noorwali, 
2013; Taylor, 2005), where excess stock was retained to act as a buffer against poor quality products (Jiménez et al., 2012) and when purchase of raw materials in small quantities was either impossible (Tanco et al., 2013) or they remained unused (Shobha and Subramanya, 2012).

\subsubsection{Over production}

As a lean waste, overproduction was evident during food processing and food service for relatively similar reasons i.e. misalignment of production with consumer demand for ready to eat foods (Darlington and Rahimifard, 2006) and poor demand forecasts where food was usually produced without orders in a hospital kitchen respectively (Engelund et al., 2009). Consequently, excess food could be thrown away.

\subsubsection{Inappropriate processing}

Mainly during food processing in three studies, did this waste occur encompassing incorrect topping, overbaking and unstandardized slicing (Sathiyabama and Dasan, 2013), poor timing of slicing operation (Goriwondo et al., 2011) and incorrect forming with loss processing materials (frying oil and crumbs) (Kennedy et al., 2013). The nutrient losses that could occur at this stage were mainly due to overbaking of bread (Sathiyabama and Dasan, 2013), inappropriate peeling, washing and pasteurization of peaches (Folinas et al., 2015).

[Insert Table 3 here]

\section{Discussion}

In search for innovative measures against FLW, hence minimize the dependency on costly efforts to increase food production, our review demonstrates a mix of countries where the applicability of VSM in the agri-food industry has been examined. Its use is not limited to developed countries, which gives an indication that such lean manufacturing practices can be successfully adopted in different settings, especially because FLW are also present in developing countries (Hodges et al., 2011). While the majority of studies were conducted at a 
single plant level, there is a growing interest of analysing FLW through applying VSM at supply chain level. These multi-level studies confirm the presence of FLW hotspots from farm to fork. In other words, tackling FLW requires an all-inclusive mitigation approach, which was also recommended by the Food and Agricultural Organisation (Gustavsson et al., 2011). This is further supported by the fact that FLW occurring at a certain point are often initiated at a preceding stage(s) of the supply chain (Beretta et al., 2013). The underlying causes of such losses and wastes were often present at various levels, regardless of the targeted food product, region and or possible difference in other study characteristics (Buzby and Hyman, 2012). As a result, the current review illustrates that VSM is adaptable to a wide range of food products likely to be lost or wasted at different stages of the chain, in line with previous studies (Gustavsson et al., 2011; Parfitt et al., 2010). Therefore, from an analytical point of view, a multi-stakeholder approach is needed to involve key actors to examine losses and wastes, as well as determine and evaluate industry-driven mitigation measures (Göbel et al., 2015; Halloran et al., 2014). This further exemplifies a shift in lean philosophy from a shop-floor quality management approach (Hines et al., 2004) to one that is chain based, which directly feeds into Supply Chain Management theory (Antony et al., 2012; Pagell and $\mathrm{Wu}, 2009)$.

In order to realise the benefits attributed to applying VSM as an approach to identify and eliminate wastes, it is necessary to use validated tools associated with this methodology adequately (Malmbrandt and Åhlström, 2013). While both current and future state maps should form a basis for successfully using VSM (Serrano Lasa et al., 2008), not all studies apply them as recommended. In theory, states maps should facilitate the assessment and quantification of performance indicators in order to justify lean implementation. However, our findings show the difficulty practitioners could face while elucidating the impact of lean practices if only the current state map or no map is included i.e. failure to satisfactorily 
illustrate performance improvements. Regarding the use of lean metrics, lead time was the most applied performance indicator accompanying VSM in agri-food sectors that adopted lean manufacturing. A reduction in lead time, when both current and future states were compared, fosters satisfaction of customer needs through quicker supply responses to demand of a given product. This is in line with the findings of De Treville et al. (2004) who shows improved performance of demand chains, with actors gaining better competitive capabilities, in markets when lead time is lowered. This is of particular importance in the agri-food industry mostly characterized by perishable food products which need to be delivered to the consumer at a considerable level of freshness lest they be discarded as waste (Kaipia et al., 2013; Mahalik and Nambiar, 2010). Likewise, a production process with waiting moments, where no value added activity is taking place, indicates the need to reduce or divert resources used to other value adding processes in order to save costs i.e. reduction in the number of operators, previously identified as an important component of activity costs (Rivera and Chen, 2007), can lower production costs as well as still improve efficiency. With respect to assertions previously made on challenges faced when applying lean tools in a non-discrete agri-food sector (Panwar et al., 2015), based on our findings, there is a high compatibility between VSM and other lean techniques (particularly JIT and 5S applied in most studies) that can be applied concurrently. These strategies are indeed relevant to boost continuous improvement in the agri-food industry.

As a complementary tool to VSM, simulation was sometimes used to address the apparent need for justifiable and practical evidence, hence further enhance potential adoption of lean practices. These studies were successful in statistically predicting various future states so as to facilitate the process of making decisions toward adoption of lean practices. Consequently, prospective but sceptic lean implementers can assess the desired impact by determining improvements in performance of their production activities in a dynamic rather than static way (Abdulmalek and Rajgopal, 2007; Lian and Van Landeghem, 2007). In this context, 
simulation can be readily applied in the agri-food industry which is characterised by unique and complex factors that, at present, often hinder the adoption of lean manufacturing practices (Dora et al., 2016). Thus, future research in the agri-food industry should prioritize investigations that target ways in which simulation models can be reliably incorporated into the VSM methodology.

Two forms of food supply chain losses and wastes (i.e. discard and nutrient loss) and associated causes related to food and nutrition were identified. Thereby, discarded food is mainly attributed to defects, inappropriate processing, unnecessary inventory and overproduction waste categories as described in lean manufacturing. Consequently, the association between non-conformance to specifications and defects in food products is explicitly highlighted in the agri-food industry. In concurrence with previous studies (Beretta et al., 2013; Göbel et al., 2015; Halloran et al., 2014), various forms of avoidable FLW that occur along the supply chain are particularly explained by failure of discarded food products to match specific quality standards i.e. deviations in size, weight, shape, breakages and shortened shelf life due to microbial contamination, similar to our findings. Furthermore, activities performed during processing of food ably cause losses and wastes especially if operations and equipment used are not standardized (Papargyropoulou et al., 2014; Parfitt et al., 2010). This points to a need to introduce process controls not only during internal processing but also extend them to other supply chain operations in order to achieve a holistic reduction of waste (Mena et al., 2014). Having excess food stock or preparing greater quantities of food than needed due to poor demand forecasting is also highlighted as a growing and major source of food waste in both developed and developing countries (Buzby and Hyman, 2012; Silvennoinen et al., 2015). In lean manufacturing, pull strategy that underlies Just-In-Time production principle facilitates the initiation of a production process based on existing demand, which in turn prevents overproduction and accumulation of 
inventory (Lyonnet and Toscano, 2014; Mackelprang and Nair, 2010). As such, food producers as well as other chain actors should be encouraged to coordinate and focus on gaining critical awareness of consumer behaviour, needs and preferences beforehand, so as to reliably predict food demand among target markets as Taylor and Fearne (2009) suggest. This and other food surplus management practices such as donation for food aid can contribute toward the fight against food insecurity (Garrone et al., 2014). Likewise in the food service industry, a previous study by Betz et al. (2015), emphasized the importance of creating awareness among staff and customers about causes of food waste and possible mitigation approaches, which further highlights the need to consider the consumption level as part of the supply chain. Food processing techniques may have a profound effect on the nutrient content of food and instances when heat treatment is applied to food products were underpinned in the findings i.e. overbaking and pasteurization may result into loss of thermal labile micronutrients. Previous studies show that nutrients such as thiamine, vitamin A and C are lost not only when excessive heat is applied (Henry and Heppell, 2002) but also with modest heat treatments in the right combination of oxygen, light and pH (Lešková et al., 2006). Other physical processing practices involving cutting, peeling, milling and more so if accompanied by washing also potentially result into micronutrient losses (Atungulu and Pan, 2014; Francis et al., 2012). This implies that VSM could not only be effective at identifying FLW but also nutrient losses. Hence, research in agri-food industry should also consider development of innovative strategies and methodologies that integrate both types of losses along the supply chain, as the current evidence shows that both kinds of losses could be attributed to the similar causes.

There are important limitations to highlight. Only case-studies with at least one food product and type of supply chain actor were included in the systematic review. Although this may be a threat to the generalizability of results to other contexts, the lean practice i.e. VSM which is 
the focus of this review suits a case study design, because it enables a deeper understanding of the current state of affairs of a production process, through a combination of qualitative and quantitative methods, in order to conceptualise a future improved state. Another limitation is that few studies included more than one supply chain actor and as a result some expected results were not observed. For example over production was only present at processing and food service levels and not at primary production. It is important that future studies dealing with lean manufacturing in particular VSM should include at least one supply chain actor, ideally including primary production where overproduction FLW are common. Furthermore, not all primary studies included performance indicators and for some that did, a relevant quantification was not given. This in turn made it difficult to extract data that could be used to show the impact of lean implementation. An imbalance in the origin of studies was observed, as majority originated from developed countries. This could have introduced some bias in the results. Still, the current results as explained in preceding sections and strengths inherent to the review justify the importance of this piece of work. First is use of an approach that can depict that FLW occur along the entire supply chain. There are few studies that have been conducted empirically from farm to fork. Although previous studies mention the need to tackle this problem in a holistic manner, they fail to move from the rhetoric to application. The current review, by illustrating that FLW actually occur along the entire supply chain, supports the need for a multi-stakeholder approach and further highlight the mitigation potential of VSM. A second strength concerns establishing possible links of nutritional value with FLW. There is no study yet with a clear explanation of such associations and so VSM potentially addresses weaknesses previously highlighted in food loss and wastage assessment methods (Affognon et al., 2015), through careful identification and mapping of hotspots where losses occur along the supply chain, and ensure a novel integration of both quantity and quality loss assessments. The third strength of the review is a compilation of literature 
from various studies to come up with a comprehensive overview of a relevant topic with a specific focus on VSM.

\section{Conclusions}

Although lean implementation in the agri-food industry is still growing, the potential of VSM has been clearly illustrated in this review. Regardless of the challenges of identification and quantification of FLW along the supply chain, VSM has shown to improve the visibility of the entire value stream (i.e. identification of FLW hotspots) and consequently creates an opening for information sharing that is necessary to reduce FLW in an integrated food system (i.e. multi-stakeholder approach relevant for Supply Chain Management). These findings have wider implications with regards to the efforts employed to improve food and nutrition security in the context of minimizing FLW. First, this approach could be a way to increase the quantity of food, made available without expanding food production per se. Second, such lean practices inherently improve production efficiency and through reduction of production costs, prices of nutritious foods could go down in favour of the vulnerable and hungry population. Furthermore, identification of hotspots where nutrient losses occur is a gateway to targeted value chain approaches for nutrition benefits (Hawkes and Ruel, 2012), that ensure nutrient retention is upheld as much as possible at all stages of the food supply chain. This review therefore offers innovative insights for future scientific research and policy practice to extend the application knowledge of VSM as an unexplored and complementary approach, with potential to sustainably enhance both food and nutrition security through minimising FLW together with nutrient losses, rather than only focusing on increasing food production.

\section{Acknowledgements}

JW is indebted to BOF (Special Research Fund - 01W01515) of Ghent University. 


\section{References}

Abdulmalek, F.A., Rajgopal, J., 2007. Analyzing the benefits of lean manufacturing and value stream mapping via simulation: A process sector case study. International Journal of production economics 107, 223-236.

Affognon, H., Mutungi, C., Sanginga, P., Borgemeister, C., 2015. Unpacking postharvest losses in sub-Saharan Africa: a meta-analysis. World Development 66, 49-68. 
Ahmed, M., Jones, E., Redmond, E., Hewedi, M., Wingert, A., Gad El Rab, M., 2015. Food production and service in UK hospitals. International Journal of Health Care Quality Assurance 28, 40-54.

Almdal, T., Viggers, L., Beck, A.M., Jensen, K., 2003. Food production and wastage in relation to nutritional intake in a general district hospital-wastage is not reduced by training the staff. Clinical Nutrition 22, 47-51.

Antony, J., Agus, A., Shukri Hajinoor, M., 2012. Lean production supply chain management as driver towards enhancing product quality and business performance: Case study of manufacturing companies in Malaysia. International Journal of Quality \& Reliability Management 29, 92-121.

Artés, F., Gómez, P., Artés-Hernández, F., 2007. Physical, physiological and microbial deterioration of minimally fresh processed fruits and vegetables. Food Science and Technology International 13, 177-188.

Atungulu, G.G., Pan, Z., 2014. Rice industrial processing worldwide and impact on macroand micronutrient content, stability, and retention. Annals of the New York Academy of Sciences 1324, 15-28.

Barrett, D.M., Beaulieu, J.C., Shewfelt, R., 2010. Color, flavor, texture, and nutritional quality of fresh-cut fruits and vegetables: desirable levels, instrumental and sensory measurement, and the effects of processing. Critical reviews in food science and nutrition 50, 369-389.

Barton, A., Beigg, C., Macdonald, I., Allison, S., 2000. High food wastage and low nutritional intakes in hospital patients. Clinical Nutrition 19, 445-449.

Beretta, C., Stoessel, F., Baier, U., Hellweg, S., 2013. Quantifying food losses and the potential for reduction in Switzerland. Waste management 33, 764-773.

Betz, A., Buchli, J., Göbel, C., Müller, C., 2015. Food waste in the Swiss food service industry-Magnitude and potential for reduction. Waste Management 35, 218-226.

Brinkman, H.-J., de Pee, S., Sanogo, I., Subran, L., Bloem, M.W., 2010. High food prices and the global financial crisis have reduced access to nutritious food and worsened nutritional status and health. The Journal of nutrition 140, 153S-161S.

Buzby, J.C., Hyman, J., 2012. Total and per capita value of food loss in the United States. Food Policy 37, 561-570.

Dal Forno, A.J., Pereira, F.A., Forcellini, F.A., Kipper, L.M., 2014. Value Stream Mapping: a study about the problems and challenges found in the literature from the past 15 years about application of Lean tools. The International Journal of Advanced Manufacturing Technology 72, 779-790. 
Darlington, R., Rahimifard, S., 2006. A responsive demand management framework for the minimization of waste in convenience food manufacture. International Journal of Computer Integrated Manufacturing 19, 751-761.

De Treville, S., Shapiro, R.D., Hameri, A.-P., 2004. From supply chain to demand chain: the role of lead time reduction in improving demand chain performance. Journal of Operations Management 21, 613-627.

Dora, M., Kumar, M., Gellynck, X., 2016. Determinants and barriers to lean implementation in food-processing SMEs-a multiple case analysis. Production Planning \& Control 27, 1-23.

Dora, M., Van Goubergen, D., Kumar, M., Molnar, A., Gellynck, X., 2014. Application of lean practices in small and medium-sized food enterprises. British Food Journal 116, 125 141.

Edwards, J.S., Nash, A.H., 1999. The nutritional implications of food wastage in hospital food service management. Nutrition \& Food Science 99, 89-98.

Engelund, E.H., Breum, G., Friis, A., 2009. Optimisation of large-scale food production using Lean Manufacturing principles. Journal of foodservice 20, 4-14.

Folinas, D.K., Aidonis, D., Karayannakidis, P., 2015. Greening the canned peach production. Journal of Agricultural Informatics 6, 24-39.

Francis, G., Gallone, A., Nychas, G., Sofos, J., Colelli, G., Amodio, M., Spano, G., 2012. Factors affecting quality and safety of fresh-cut produce. Critical reviews in food science and nutrition 52, 595-610.

Francis, M., Simons, D., Bourlakis, M., 2008. Value chain analysis in the UK beef foodservice sector. Supply chain management: an international journal 13, 83-91.

Frewer, L.J., van der Lans, I.A., Fischer, A.R., Reinders, M.J., Menozzi, D., Zhang, X., van den Berg, I., Zimmermann, K.L., 2013. Public perceptions of agri-food applications of genetic modification-a systematic review and meta-analysis. Trends in Food Science \& Technology 30, 142-152.

Garrone, P., Melacini, M., Perego, A., 2014. Opening the black box of food waste reduction. Food policy 46, 129-139.

Gil, M.I., Aguayo, E., Kader, A.A., 2006. Quality changes and nutrient retention in fresh-cut versus whole fruits during storage. Journal of Agricultural and Food chemistry 54, 42844296.

Glover, W.J., Poopunsri, T., Hurley, R., 2014. Applying Lean to Non-Profit Organizations: A Food Bank Case Study, IIE Annual Conference. Proceedings. Institute of Industrial Engineers-Publisher, p. 274. 
Göbel, C., Langen, N., Blumenthal, A., Teitscheid, P., Ritter, G., 2015. Cutting food waste through cooperation along the food supply chain. Sustainability 7, 1429-1445.

Godfray, H.C.J., Beddington, J.R., Crute, I.R., Haddad, L., Lawrence, D., Muir, J.F., Pretty, J., Robinson, S., Thomas, S.M., Toulmin, C., 2010. Food security: the challenge of feeding 9 billion people. science 327, 812-818.

Goriwondo, W.M., Marecha, A., Mhlanga, S., 2011. Use of the Value Stream Mapping tool for Waste Reduction In Manufacturing. Case Study for Bread Manufacturing In Zimbabwe.

Gustavsson, J., Cederberg, C., Sonesson, U., van Otterdijk, R., Meybeck, A., 2011. Global food losses and food waste: extent, causes and prevention. Report by the Swedish Institute for Food and Biotechnology for the Food and Agriculture Organization of the United Nations: Rome.

Halloran, A., Clement, J., Kornum, N., Bucatariu, C., Magid, J., 2014. Addressing food waste reduction in Denmark. Food Policy 49, 294-301.

Hanjra, M.A., Ferede, T., Blackwell, J., Jackson, T., Abbas, A., 2013. Global food security: facts, issues, interventions and public policy implications.

Hawkes, C., Ruel, M.T., 2012. Value chains for nutrition. Reshaping agriculture for nutrition and health, 73-82.

Henry, C., Heppell, N., 2002. Nutritional losses and gains during processing: future problems and issues $\dagger$. Proceedings of the Nutrition Society 61, 145-148.

Hines, P., Holweg, M., Rich, N., 2004. Learning to evolve: a review of contemporary lean thinking. International journal of operations \& production management 24, 994-1011.

Hines, P., Rich, N., 1997. The seven value stream mapping tools. International journal of operations \& production management 17, 46-64.

Hodges, R.J., Buzby, J.C., Bennett, B., 2011. Postharvest losses and waste in developed and less developed countries: opportunities to improve resource use. The Journal of Agricultural Science 149, 37-45.

Hossain, M.M., Uddin, M.K., 2015. An Approach to Improve the Process Cycle Efficiency and Reduce the Lead Time of a Mango Juice Processing Line by Using Lean Tools: A Case Study. International Journal of Scientific \& Engineering Research 6.

Hsieh, H.-F., Shannon, S.E., 2005. Three approaches to qualitative content analysis. Qualitative health research 15, 1277-1288.

Jiménez, E., Tejeda, A., Pérez, M., Blanco, J., Martínez, E., 2012. Applicability of lean production with VSM to the Rioja wine sector. International Journal of Production Research 50, 1890-1904. 
Kaipia, R., Dukovska-Popovska, I., Loikkanen, L., 2013. Creating sustainable fresh food supply chains through waste reduction. International journal of physical distribution \& logistics management 43, 262-276.

Kennedy, I., Plunkett, A., Haider, J., 2013. Implementation of Lean Principles in a Food Manufacturing Company, Advances in Sustainable and Competitive Manufacturing Systems. Springer, pp. 1579-1590.

Kumar, S., Kumar, N., Vivekadhish, S., 2016. Millennium development goals (MDGS) to sustainable development goals (SDGS): Addressing unfinished agenda and strengthening sustainable development and partnership. Indian journal of community medicine: official publication of Indian Association of Preventive \& Social Medicine 41, 1.

Kummu, M., De Moel, H., Porkka, M., Siebert, S., Varis, O., Ward, P., 2012. Lost food, wasted resources: Global food supply chain losses and their impacts on freshwater, cropland, and fertiliser use. Science of the Total Environment 438, 477-489.

Lehtinen, U., Torkko, M., 2005. The Lean concept in the food industry: a case study of a contract manufacturer. Journal of Food Distribution Research 36, 57.

Lešková, E., Kubíková, J., Kováčiková, E., Košická, M., Porubská, J., Holčíková, K., 2006. Vitamin losses: retention during heat treatment and continual changes expressed by mathematical models. Journal of Food Composition and analysis 19, 252-276.

Lian, Y.-H., Van Landeghem, H., 2007. Analysing the effects of Lean manufacturing using a value stream mapping-based simulation generator. International Journal of Production Research 45, 3037-3058.

Lyonnet, B., Toscano, R., 2014. Towards an adapted lean system-a push-pull manufacturing strategy. Production Planning \& Control 25, 346-354.

Mackelprang, A.W., Nair, A., 2010. Relationship between just-in-time manufacturing practices and performance: A meta-analytic investigation. Journal of Operations Management 28, 283-302.

Mahalik, N.P., Nambiar, A.N., 2010. Trends in food packaging and manufacturing systems and technology. Trends in Food Science \& Technology 21, 117-128.

Malmbrandt, M., Åhlström, P., 2013. An instrument for assessing lean service adoption. International Journal of Operations \& Production Management 33, 1131-1165.

Melvin, A., Baglee, D., 2008. Value stream mapping: A dairy industry prospective, Engineering Management Conference, IEMC Europe, pp. 1-5.

Mena, C., Terry, L.A., Williams, A., Ellram, L., 2014. Causes of waste across multi-tier supply networks: Cases in the UK food sector. International Journal of Production Economics 152, 144-158. 
Miller, D.D., Welch, R.M., 2013. Food system strategies for preventing micronutrient malnutrition. Food Policy 42, 115-128.

Munesue, Y., Masui, T., Fushima, T., 2015. The effects of reducing food losses and food waste on global food insecurity, natural resources, and greenhouse gas emissions. Environmental Economics and Policy Studies 17, 43-77.

Murthy, D.S., Gajanana, T., Sudha, M., Dakshinamoorthy, V., 2009. Marketing and postharvest losses in fruits: its implications on availability and economy. Marketing 64.

Noorwali, A., 2013. Apply Lean and Taguchi in Different Level of Variability of Food Flow Processing System. Procedia Engineering 63, 728-734.

Pace, R., Pluye, P., Bartlett, G., Macaulay, A.C., Salsberg, J., Jagosh, J., Seller, R., 2012. Testing the reliability and efficiency of the pilot Mixed Methods Appraisal Tool (MMAT) for systematic mixed studies review. International journal of nursing studies 49, 47-53.

Pagell, M., Wu, Z., 2009. Building a more complete theory of sustainable supply chain management using case studies of 10 exemplars. Journal of supply chain management 45, 3756.

Pangaribowo, E.H., Gerber, N., Torero, M., 2013. Food and nutrition security indicators: a review. Center for Development Research (ZEF), University of Bonn, Bonn, Germany.

Panwar, A., Nepal, B.P., Jain, R., Rathore, A.P.S., 2015. On the adoption of lean manufacturing principles in process industries. Production Planning \& Control 26, 564-587.

Papargyropoulou, E., Lozano, R., Steinberger, J.K., Wright, N., bin Ujang, Z., 2014. The food waste hierarchy as a framework for the management of food surplus and food waste. Journal of Cleaner Production 76, 106-115.

Parfitt, J., Barthel, M., Macnaughton, S., 2010. Food waste within food supply chains: quantification and potential for change to 2050. Philosophical Transactions of the Royal Society B: Biological Sciences 365, 3065-3081.

Parthanadee, P., Buddhakulsomsiri, J., 2014. Production efficiency improvement in batch production system using value stream mapping and simulation: a case study of the roasted and ground coffee industry. Production Planning \& Control 25, 425-446.

Petticrew, M., Roberts, H., 2008. Systematic reviews in the social sciences: A practical guide. John Wiley \& Sons.

Phalan, B., Onial, M., Balmford, A., Green, R.E., 2011. Reconciling food production and biodiversity conservation: land sharing and land sparing compared. Science 333, 1289-1291.

Pluye, P., Gagnon, M.-P., Griffiths, F., Johnson-Lafleur, J., 2009. A scoring system for appraising mixed methods research, and concomitantly appraising qualitative, quantitative 
and mixed methods primary studies in Mixed Studies Reviews. International journal of nursing studies 46, 529-546.

Rahimnia, F., Moghadasian, M., Castka, P., 2009. Benchmarking leagility in mass services: The case of a fast food restaurant chains in Iran. Benchmarking: An International Journal 16, 799-816.

Richter, B., Bokelmann, W., 2016. Approaches of the German food industry for addressing the issue of food losses. Waste Management 48, 423-429.

Rivera, L., Chen, F.F., 2007. Measuring the impact of Lean tools on the cost-time investment of a product using cost-time profiles. Robotics and Computer-Integrated Manufacturing 23, 684-689.

Rother, M., Shook, J., 1998. Learning to See: Value Stream Mapping to Create Value and Eliminate Muda. v. 1.1. Oct., The Lean Enterprise Inst., Brookline, Mass.

Ruel, M.T., Alderman, H., Maternal, Group, C.N.S., 2013. Nutrition-sensitive interventions and programmes: how can they help to accelerate progress in improving maternal and child nutrition? The Lancet 382, 536-551.

Rutten, M., Verma, M., Mhlanga, N., Bucatariu, C., 2015. Potential impacts on sub-Saharan Africa of reducing food loss and waste in the European Union - A focus on food prices and price transmission effects. FAO/LEI, Rome, Italy.

Rutten, M.M., 2013. What economic theory tells us about the impacts of reducing food losses and/or waste: implications for research, policy and practice. Agriculture \& Food Security 2, 13.

Sa'udah, N., Amit, N., Ali, M.N., 2015. Facility Layout for SME Food Industry via Value Stream Mapping and Simulation. Procedia Economics and Finance 31, 797-802.

Sachs, J.D., 2012. From millennium development goals to sustainable development goals. The Lancet 379, 2206-2211.

Sathiyabama, C.N., Dasan, P., 2013. Optimum Resource Allocation and Eliminating Waste Inside Food Industry. Central European Business Review 2, 31.

Searchinger, T., Hanson, C., Ranganathan, J., Lipinski, B., Waite, R., Winterbottom, R., Dinshaw, A., Heimlich, R., 2013. "The great balancing act" Creating a Sustainable Food Future Working Paper 1. World Resources Institute, Washington, DC.

Serrano Lasa, I., Ochoa Laburu, C., de Castro Vila, R., 2008. An evaluation of the value stream mapping tool. Business Process Management Journal 14, 39-52. 
Seth, D., Seth, N., Goel, D., 2008. Application of value stream mapping (VSM) for minimization of wastes in the processing side of supply chain of cottonseed oil industry in Indian context. Journal of Manufacturing Technology Management 19, 529-550.

Shobha, N., Subramanya, K., 2012. Application of Value Stream Mapping for Process Improvement in a Food Manufacturing Industry-A Case Study, International Conference on Challenges and Opportunities in Mechanical Engineering, Industrial Engineering and Management Studies.

Silvennoinen, K., Heikkilä, L., Katajajuuri, J.-M., Reinikainen, A., 2015. Food waste volume and origin: Case studies in the Finnish food service sector. Waste Management 46, 140-145.

Simons, D., Francis, M., Bourlakis, M., Fearne, A., 2003. Identifying the determinants of value in the UK red meat industry: A value chain analysis approach. Journal on Chain and Network Science 3, 109-121.

Souto, R.Q., Khanassov, V., Hong, Q.N., Bush, P.L., Vedel, I., Pluye, P., 2015. Systematic mixed studies reviews: updating results on the reliability and efficiency of the mixed methods appraisal tool. International journal of nursing studies 52, 500-501.

Tanco, M., Santos, J., Rodriguez, J.L., Reich, J., 2013. Applying lean techniques to nougat fabrication: a seasonal case study. The International Journal of Advanced Manufacturing Technology 68, 1639-1654.

Taylor, D.H., 2005. Value chain analysis: an approach to supply chain improvement in agrifood chains. International Journal of Physical Distribution \& Logistics Management 35, 744761.

Taylor, D.H., 2006a. Demand management in agri-food supply chains: an analysis of the characteristics and problems and a framework for improvement. The international journal of logistics management 17, 163-186.

Taylor, D.H., 2006b. Strategic considerations in the development of lean agri-food supply chains: a case study of the UK pork sector. Supply Chain Management: An International Journal 11, 271-280.

Taylor, D.H., Fearne, A., 2009. Demand management in fresh food value chains: a framework for analysis and improvement. Supply Chain Management: An International Journal 14, 379-392.

Vlachos, I., 2015. Applying lean thinking in the food supply chains: a case study. Production Planning \& Control 26, 1351-1367.

Wheeler, T., von Braun, J., 2013. Climate change impacts on global food security. Science 341, 508-513. 
Willersinn, C., Mack, G., Mouron, P., Keiser, A., Siegrist, M., 2015. Quantity and quality of food losses along the Swiss potato supply chain: Stepwise investigation and the influence of quality standards on losses. Waste Management 46, 120-132.

Womack, J.P., 2006. Value stream mapping. Manufacturing Engineering 136, 145-156.

Womack, J.P., Jones, D.T., Roos, D., 1990. Machine that changed the world. Simon and Schuster.

Yu, M., Nagurney, A., 2013. Competitive food supply chain networks with application to fresh produce. European Journal of Operational Research 224, 273-282.

Zokaei, K., Simons, D., 2006a. Performance improvements through implementation of lean practices: a study of the UK red meat industry. International Food and Agribusiness Management Review 9, 30-53.

Zokaei, K., Simons, D., 2006b. Value chain analysis in consumer focus improvement: A case study of the UK red meat industry. The International Journal of Logistics Management 17, 141-162.

Table 1: Tool used for Quality assessment of included studies

\begin{tabular}{ll}
\hline Quality parameter & Operationalization (Yes $=1$, No $=0$ ) \\
\hline Data sources & Are the data sources relevant to the objective? \\
Sampling & Is the sampling approach appropriate and is the sample representative of the study \\
& population? \\
Analysis & Is data analysed appropriately to address the objective? \\
Context & Do results relate appropriately to the context used for data collection? \\
Measurements & Are recommended measurements used appropriately? \\
\hline Source: Adapted from Pluye et al. (2009), Pace et al. (2012) and Souto et al. (2015)
\end{tabular}


Table 2: Overview of key characteristics and performance of case-studies applying Value Stream Mapping, classified by level of analysis

\begin{tabular}{|c|c|c|c|c|c|c|c|c|c|c|c|c|}
\hline Level of analysis & $\begin{array}{l}\text { Chain } \\
\text { actor }\end{array}$ & Entity & Type of food & Country & Year & $\begin{array}{l}\text { Method of data } \\
\text { collection }\end{array}$ & VSM State maps & Other tools $^{\mathrm{a}}$ & $\begin{array}{l}\text { Performance } \\
\text { Lean } \text { metric }^{b}\end{array}$ & $\frac{\text { dicators }}{\text { Reduction }}$ & Reference & $\begin{array}{l}\text { Quality } \\
\text { Score }\end{array}$ \\
\hline \multirow[t]{19}{*}{ Single Plant level } & Processor & Food factory & Bread & United Kingdom & 2013 & Interview \& observation & Current \& future* & $\overline{5 S}$ & $\begin{array}{l}\text { Lead time } \\
\text { Operators }\end{array}$ & $\begin{array}{l}49 \% \\
33 \%-40 \% \\
\end{array}$ & $\begin{array}{c}\text { (Sathiyabama and Dasan, } \\
\text { 2013) }\end{array}$ & 4 \\
\hline & & & & $\overline{\text { Zimbabwe }}$ & 2011 & Interview \& observation & Current \& future & - & Lead time & $25 \%$ & (Goriwondo et al.., 2011) & 3 \\
\hline & & & $\begin{array}{l}\text { Ready to eat } \\
\text { foods }\end{array}$ & United Kingdom & 2006 & Interview & Current & $\begin{array}{l}\text { JIT } \\
\text { Simulation }\end{array}$ & Lead time & $N D$ & $\begin{array}{l}\text { (Darlington and Rahimifard, } \\
\text { 2006) }\end{array}$ & 3 \\
\hline & & & & & 2013 & Observation \& records & Current & $5 \mathrm{~S}$ & - & $N D$ & (Kennedy et al., 2013) & 3 \\
\hline & & & Peaches & Greece & 2015 & Interview \& records & Current \& future & JIT & $\begin{array}{l}\text { Lead time } \\
\text { Operators }\end{array}$ & $\begin{array}{l}N D \\
N D\end{array}$ & (Folinas et al., 2015) & 4 \\
\hline & & & Wine & Spain & 2012 & Not mentioned & Current \& future & $\begin{array}{l}5 \mathrm{~S} \\
\text { JIT } \\
\text { Kanban }\end{array}$ & Lead time & $63 \%$ & (Jiménez et al., 2012) & 4 \\
\hline & & & Mango juice & Bangladesh & 2015 & Not mentioned & Current \& future & $\frac{5 S}{\mathrm{JIT}}$ & $\begin{array}{l}\text { Lead time } \\
\text { Takt time } \\
\text { Operators }\end{array}$ & \begin{tabular}{|l|}
$55 \%$ \\
$2 \%$ \\
$32 \%$
\end{tabular} & (Hossain and Uddin, 2015) & 4 \\
\hline & & & Ketchup & Finland & 2005 & Interview \& observation & Current & Visual aids & Lead time & $N D$ & (Lehtinen and Torkko, 2005) & 3 \\
\hline & & & Yogurt & United Kingdom & 2008 & Interview \& observation & Current & - & - & $N D$ & (Melvin and Baglee, 2008) & 3 \\
\hline & & & Biscuit & Saudi Arabia & 2013 & Not mentioned & Current* & Simulation & - & $N D$ & (Noorwali, 2013) & 3 \\
\hline & & & & India & 2012 & Observation & Current \& future & \begin{tabular}{l|} 
JIT \\
Kanban
\end{tabular} & $\begin{array}{l}\text { Lead time } \\
\text { Operators }\end{array}$ & $\begin{array}{l}15 \% \\
7 \%\end{array}$ & $\begin{array}{l}\text { (Shobha and Subramanya, } \\
\text { 2012) }\end{array}$ & 4 \\
\hline & & & Coffee & Thailand & 2014 & Not mentioned & Current \& future & Simulation & Operators & $13 \%$ & $\begin{array}{c}\text { (Parthanadee and } \\
\text { Buddhakulsomsiri, 2014) }\end{array}$ & 4 \\
\hline & & & Snacks & Malaysia & 2015 & Observation & Current \& future & Simulation & Lead time & $3 \%$ & (Sa’udah et al., 2015) & 4 \\
\hline & & & Nougat & Uruguay & 2013 & Observation & Current \& future & $\begin{array}{l}\text { JIT } \\
\text { Simulation }\end{array}$ & Lead time & $83 \%$ & (Tanco et al., 2013) & 4 \\
\hline & & & $\overline{\text { Tea }}$ & $\begin{array}{l}\text { United Kingdom } \\
\text { India }\end{array}$ & 2015 & $\begin{array}{l}\text { Interview, observation \& } \\
\text { records }\end{array}$ & Current & JIT & Lead time & $N D$ & (Vlachos, 2015) & 3 \\
\hline & Storage & Food warehouse & Variety & United States & 2014 & Observation & Current $\&$ future & $5 S$ & Lead time & $83 \%$ & (Glover et al., 2014) & 4 \\
\hline & Consumer & Hospital kitchen & Variety & United Kingdom & 2015 & Interview \& focus group & Current & - & - & $N D$ & (Ahmed et al., 2015) & 4 \\
\hline & & & Variety & Denmark & 2009 & Interview \& observation & Current $\&$ future* & $5 S$ & Operators & $24 \%$ & (Engelund et al., 2009) & 3 \\
\hline & & Food restaurant & Fast foods & Iran & 2009 & Interview & Current \& future & $\begin{array}{l}\text { Cellular } \\
\text { Manufacturing }\end{array}$ & Lead time & $75 \%$ & (Rahimnia et al., 2009) & 5 \\
\hline \multirow[t]{5}{*}{ Supply chain level } & $\begin{array}{l}\text { Farmer } \\
\text { Processor }\end{array}$ & $\begin{array}{l}\text { Farm } \\
\text { Food factory }\end{array}$ & Beef & $\begin{array}{l}\text { United Kingdom } \\
\text { Argentina }\end{array}$ & 2008 & Observation & Current & Visual aids & - & $N D$ & (Francis et al., 2008) & 4 \\
\hline & Farmer & Farm & Edible oil & India & 2008 & Interview \& observation & Current \& future & - & Lead time & $93 \%$ & (Seth et al., 2008) & 5 \\
\hline & Processor & Food factory & Lamb & United Kingdom & 2003 & Interview \& observation & Current & - & Cycle time & $N D$ & (Simons et al., 2003) & 4 \\
\hline & Sale Point & Wholesale/retailer & Pork & United Kingdom & 2005 & Interview \& observation & Current \& future & JIT & Lead time & $N D$ & (Taylor, 2005) & 5 \\
\hline & & & & & 2006 & Interview \& observation & Current & JIT & Lead time & $N D$ & (Taylor, 2006b) & 4 \\
\hline
\end{tabular}


Table 3: Hotspots and wastes and their causes derived from agri-food studies applying Value Stream Mapping, split up according to stage

\begin{tabular}{|c|c|c|c|c|}
\hline Hotspot & Form of loss/waste & Lean waste & Cause of waste & Reference \\
\hline \multirow[t]{3}{*}{ Primary production } & \multirow[t]{3}{*}{ Discard } & \multirow[t]{2}{*}{ Unnecessary inventory } & Uncertainty in supply of raw material & (Seth et al., 2008) \\
\hline & & & Use of push production system & (Taylor, 2005, 2006b) \\
\hline & & Defect in product & Non-conformance to specifications $s^{\mathrm{a}}$ & (Taylor, 2005) \\
\hline \multirow[t]{10}{*}{ Processing } & \multirow[t]{7}{*}{ Discard } & \multirow[t]{2}{*}{ Defect in product } & Non-conformance to specifications ${ }^{\mathrm{a}}$ & $\begin{array}{l}\text { (Folinas et al., 2015; Goriwondo et } \\
\text { al., 2011; Jiménez et al., 2012; } \\
\text { Noorwali, 2013; Sathiyabama and } \\
\text { Dasan, 2013; Seth et al., 2008; } \\
\text { Shobha and Subramanya, 2012; } \\
\text { Taylor, 2005, 2006b; Vlachos, 2015) }\end{array}$ \\
\hline & & & Short shelf-life due to microbial spoilage & $\begin{array}{c}\text { (Darlington and Rahimifard, 2006; } \\
\text { Francis et al., 2008; Melvin and } \\
\text { Baglee, 2008) }\end{array}$ \\
\hline & & \multirow[t]{3}{*}{ Inappropriate processing } & Poor \& over topping, overbaking, variation in size/shape & (Sathiyabama and Dasan, 2013) \\
\hline & & & Poor timing of slicing operation & (Goriwondo et al., 2011) \\
\hline & & & Food loss due to forming and loss of processing materials & (Kennedy et al., 2013) \\
\hline & & Over production & Poor demand forecast & $\begin{array}{c}\text { (Darlington and Rahimifard, 2006; } \\
\text { Noorwali, 2013) }\end{array}$ \\
\hline & & Unnecessary inventory & Excess stock of either raw materials or finished products & $\begin{array}{l}\text { (Jiménez et al., 2012; Lehtinen and } \\
\text { Torkko, 2005; Noorwali, 2013; } \\
\text { Shobha and Subramanya, 2012; } \\
\text { Tanco et al., 2013; Taylor, 2005) }\end{array}$ \\
\hline & \multirow[t]{3}{*}{ Nutrient loss } & Defect in product & Non-conformance to specifications ${ }^{\mathrm{a}}$ & (Sathiyabama and Dasan, 2013) \\
\hline & & \multirow[t]{2}{*}{ Inappropriate processing } & Overbaking & (Sathiyabama and Dasan, 2013) \\
\hline & & & Inappropriate peeling, washing and pasteurization & (Folinas et al., 2015) \\
\hline Storage & Discard & Defect in product & Short shelf life due to microbial spoilage & (Glover et al., 2014) \\
\hline \multirow[t]{3}{*}{ Foodservice/Consumption } & \multirow[t]{3}{*}{ Discard } & \multirow[t]{2}{*}{ Defect in product } & Wrong meal service & (Ahmed et al., 2015) \\
\hline & & & Mismatch with customized needs of consumers & (Rahimnia et al., 2009) \\
\hline & & Overproduction & Poor demand forecast & (Engelund et al., 2009) \\
\hline
\end{tabular}

${ }^{a}$ Including: incorrect weight and fat levels, poor/overtopped products, variation in size/shape, breakages, scrap and/or poor quality 
